\title{
Wirausaha Dalam Meningkatkan Kesejahteraan Ekonomi Masyarakat Di Desa Baderan
}

\author{
Endang Murti ${ }^{1}$, Retno Iswati ${ }^{2}$, Agus Wiyaka ${ }^{3}$

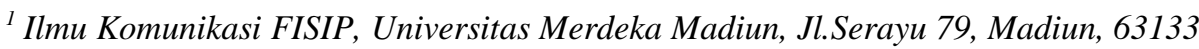 \\ E-mail: hariyani_nunik@yahoo.com \\ ${ }^{2}$ Ilmu Komunikasi FISIP, Universitas Merdeka Madiun, Jl.Serayu 79, Madiun, 63133 \\ E-mail: hariyani_nunik@yahoo.com \\ ${ }^{3}$ Ilmu Komunikasi FISIP, Universitas Merdeka Madiun, Jl.Serayu 79, Madiun, 63133 \\ E-mail: hariyani_nunik@yahoo.com
}

\begin{abstract}
Enterprise strategic role to reduce poverty by creating employment opportunities that the public interest is based on the skills / abilities of each person. Through entrepreneurship, the government can realize a more equitable and fair development for our community to maximize the potential advantages of natural resources. The growth of rural enterprises can not be separated from the community and village government contribute to helping develop the potential and village enterprises. The main thing to do is to provide convenience village government licensing submission of bank capital, promote the potential of the village passing through competitions held events in the village, provision of business training, capital support and tools with related agencies. Then participation by contributing purchase products and promote the efforts to develop WED.
\end{abstract}

Keywords - : Entrepreneurial; Welfare; Public Economy.

\section{LATAR BELAKANG}

Kewirausahaan berperan strategis untuk menurunkan kemiskinan dengan menciptakan peluang-peluang kerja diminati masyarakat berdasarkan skill/kemampuan masing-masing orang. Melalui kewirausahaan, pemerintah dapat mewujudkan pembangunan yang lebih merata dan berkeadilan bagi masyarakat serta dapat memaksimalkan keunggulan potensi-potensi sumber daya alam seringkali diminimalisirkan keberadaannya. Kemiskinan merupakan masalah pembangunan ditandai dengan pengangguran, keterbelakangan, dan keterpurukan. Masyarakat miskin lemah dalam kemampuan berusaha dan mempunyai akses terbatas kepada kegiatan sosial ekonomi. Dalam upaya penanggulangan kemiskinan ada dua strategi utama ditempuh. Pertama, melindungi keluarga dan kelompok masyarakat miskin melalui pemenuhan kebutuhan pokok mereka. Kedua, memberdayakan mereka agar mempunyai kemampuan untuk melakukan usaha dan mencegah terjadinya kemiskinan baru. Undang-Undang Republik Indonesia Nomor 11 tahun 2005 tentang Ratifikasi Kovenan Hak Ekonomi, Sosial dan Budaya. Artinya, pemerintah menjamin pemenuhan hak dasar untuk warga, sehingga kalau ada kemiskinan berarti pemerintah melanggar hak asasi manusia disepakati dalam covenant tersebut. Pembangunan melalui kesepakatan MDG's baru merupakan dasar upaya nyata dari prioritas yang terfokus, terukur, sinergis dan berkelanjutan. Pelaksanaan pembangunan yang sejati tetap berkomitmen untuk menurunkan tingkat kemiskinan secara menyeluruh, bukan hanya sebagian saja, dan pencapaian dengan waktu yang lebih cepat.

Meski pertumbuhan ekonomi terus meningkat namun belum menjamin pemerataan pendapatan. Pemerintah Kabupaten Ngawi telah menetapkan Indikator Pembangunan untuk menilai tingkat keberhasilan pencapaian kinerja pembangunan daerah dalam rangka mewujudkan Ngawi Sejahtera. Peran Pemerintah daerah dalam anggaran untuk rakyat masih rendah. Hal ini ditandai dari jumlah alokasi pada program penanganan kemiskinan dan pelayanan hak dasar (pendidikan dan kesehatan) yang minim serta pengalokasian dalam bentuk kegiatan-kegiatan yang tidak fokus. Masyarakat miskin pada umumnya lemah dalam kemampuan berusaha dan terbatas aksesnya kepada kegiatan ekonomi sehingga tertinggal jauh dari masyarakat lainnya yang mempunyai potensi lebih tinggi.

Dalam perkembangannya, pertumbuhan usaha-usaha ada di desa tak lepas dari peran serta masyarakat dan pemerintah desa berkontribusi dalam membantu mengembangkan potensi dan usaha-usaha desa ada. Hal utama dilakukan pemerintah desa adalah memberikan kemudahan dalam perijinan pengajuan modal dari bank, mempromosikan potensi desa yang ada lewat event digelar lewat lomba desa, pengadaan pelatihan usaha, bantuan permodalan dan alat-alat dengan dinas terkait. Kemudian partisipasi masyarakat dengan ikut membeli produk dan mempromosikan hasil usaha juga turut mengembangkan kewirusahaan.

Pemerintah dalam hal ini berusaha dapat membantu sektor usaha informal, home industri, industri kecil, khususnya yang diusahakan keluarga miskin atau kurang mampu yang mempunyai usaha akan dapat berkembang, dan pada akhirnya akan dapat meningkatkan kesejahteraannya. Serta untuk mendorong agar potensi ekonmi di desa-desa, khususnya potensi ekonomi yang diusahakan oleh keluarga miskin/ kurang mampu dalam bidang usaha. Lembaga masyarakat secara aktif ikut mensosialisasikan serta membangkitkan wirausaha untuk meningkatkan kesejahteraan. 


\section{KAJIAN LITERATUR}

Kewirausahaan merupakan hal-hal yang terkait dengan wirausaha. Sedangkan wira berarti keberanian dan usaha berarti kegiatan bisnis yang komersial atau non-komersial, Sehingga kewirausahaan dapat pula diartikan sebagai keberanian seseorang untuk melaksanakan suatu kegiatan bisnis. Harvey Leibenstein (1968, 1979), mengemukakan, kewirausahaan mencakup kegiatan-kegiatann yang dibutuhkan untuk menciptakan atau melaksanakan perusahaan pada saat semua pasar belum terbentuk atau belum teridentifikasi dengan jelas, atau komponen fungsi produksinya belum diketahui sepenuhnya.

(www.kompasiana.com/www.habibamin.blogspot.com/550e5459813311862cbc625d/pengertian-tujuan-dan-teorikewirausahaan-materi-kuliah. Diunduh tgl 21 Juli 2016 pukul 06.00WIB)

Menurut Indarti \& Kristiansen14, intensi wirausaha seseorang terbentuk melalui tiga tahap yaitu motivasi (motivation), kepercayaan diri (belief) serta ketrampilan dan kompetensi (Skill \& Competence). Setiap individu mempunyai keinginan (motivasi) untuk sukses. Individu yang memiliki need for achievement yang tinggi akan mempunyai usaha yang lebih untuk mewujudkan apa yang diinginkannya. Kebutuhan akan pencapaian membentuk kepercayaan diri (belief) dan pengendalian diri yang tinggi (locus of control). Pengendalian diri yang tinggi terhadap lingkungan memberikan individu keberanian dalam mengambil keputusan dan risiko yang ada. (Indarti, Nurul dan Kristiansen, Stein. 2003. Determinants of Entrepreneurial Intention: The Case of Norwegian Students dalam International Journal of Business Gadjah Mada).

Untuk itu BAPPENAS RI memiliki strategi dalam pengembangan kewirausahaan di Indonesia, diantaranya adalah: (1) Menciptakan iklim usaha yang kondusif. (2) Meningkatkan julmah wirausaha baru. (3) Meningkatkan kompetensi kewirausahaan. Dari ketiga strategi tersebut, ada ima cakupan pengembangan kewirausahaan di Indonesia, diantaranya adalah: (1) Perbaikan kurikulum, dan modul pendidikan dan pelatihan kewirausahaan. (2) Pemasyarakatan kewirausahaan melalui sosialisasi dan kompetensi. (3) Penguatan kebijakan dan sistem pendukung. (4) Pengembangan kewirausahaan sosial. (5) Kolaborasi dengan dunia usaha dan pemangku kepentingan lainnya. Keluaran dari pembangunan kewirausahaan melalui pendekatan pendidikan ini diharapkan menghasilkan masyarakat yang mampu berinovasi dengan menciptakan sesuatu yang baru dan berbeda melalui pemikiran kreatif dan tindakan inovatif melalui pengembangan teknologi, penemuan pengetahuan ilmiah, perbaikan produk barang dan jasa yang ada, ataupun menemukan cara-cara baru untuk mendapatkan produk yang lebih banyak dengan sumber daya yang lebih efisien. Pada akhirnya masyarakat diharapkan dapat memiliki kompatibilitas sebagai jalan keluar untuk menolong diri sendiri dalam meningkatkan derajat ekonomi masyarakat.

Israel Kirzner (1979): Wirausahawan mengenali dan bertindak terhadap peluang pasar. Entrepreneurship Center at Miami University of Ohio: Kewirausahaan sebagai proses mengidentifikasi, mengembangkaan, dan membawa visi ke dalam kehidupan. Visi tersebut bisa berupa ide inovatif, peluang, cara yang lebih baik dalam menjalankan sesuatu. Hasila akhir dari proses tersebut adalah penciptaan usaha baru yang dibentuk pada kondisi resiko atau ketidakpastian. Salah satu kesimpulan yang bisa ditarik dari berbagai pengertian tersebut adalah bahwa kewirausahaan dipandang sebagai fungsi yang mencakup eksploitasi peluang-peluang yang muncul di pasar. Eksploitasi tersebut sebagian besar berhubungan dengan pengarahan dan atau kombinasi input yang produktif. Seorang wirausahawan selalu diharuskan menghadapi resiko atau peluang yang muncul, serta sering dikaitkan dengan tindakan yang kreatif dan innovatif. Selain itu, seorang wirausahawan menjalankan peranan manajerial dalam kegiatannya, tetapi manajemen rutin pada operasi yang sedang berjalan tidak digolongkan sebagai kewirausahaan. Seorang individu mungkin menunjukkan fungsi kewirausahaan ketika membentuk sebuah organisasi, tetapi selanjutnya menjalankan fungsi manajerial tanpa menjalankan fungsi kewirausahaannya. Jadi kewirausahaan bisa bersifat sementara atau kondisional. (/akhsan99.wordpress.com/2009/10/14/pengertian-dan-teori-kewirausahaan/ Diunduh tgl 21 Juli 2016 pukul 07.00WIB)

Wirausaha memiliki peran yang besar dalam meningkatkan kesejahteraan masyarakat, seperti :

a. Terciptanya lapangan pekerjaan merupakan salah satu peran dari seorang wirausaha. Dengan adanya lapangan pekerjaan yang diciptakan oleh para wirausaha tentuya dapat membantu perekonomian masyarakat, sehingga dengan terciptanya lapangan pekerjaan bagi masyarakat akan dapat mengurangi tingkat kriminalitas yang ada di masyarakat.

b. Meningkatkan pendapatan masyarakat. Dengan pendapatan/hasil yang diperoleh dari wirausaha, masyarakat setidaknya dapat memenuhi kebutuhan hidup mereka . Apabila wirausaha yang ada di Indonesia dapat bertambah dari tahun ke tahun maka kemiskinan dan pengangguran dapat berkurang, dan kehidupan masyarakat pun menjadi sejahtera.

c. Mengkombinasikan faktor - faktor produksi. Seorang wirausaha merupakan orang yang kreatif dan inovatif. Karena seorang wirausaha mampu untuk mengatur dan mengolah, serta menggabungkan antara SDM dan SDA menjadi bermanfaat. Seorang wirausaha mampu mencari peluang-peluang yang baru dan tidak pernah ragu untuk mencoba/menciptakan hal-hal baru.

d. Meningkatkan produktivitas. Banyaknya wirausaha yang bermunculan tentunya dapat meningkatkan produktivitas dari berbagai produk yang diciptakan oleh para wirausaha. Produk-produk tersebut nantinya dapat bermanfaat bagi kehidupan masyarakat. Sehingga para wirausaha yang melihat peluang tersebut dapat berlomba-lomba untuk mencari inovasi yang lebih baru lagi.

e. Wirausaha juga memiliki peranan penting untuk menjadikan masyarakat lebih kreatif sehingga menghasilkan individu yang mandiri. Di Indonesia sendiri jumlah wirausaha adalah sebesar 19,3\% dari jumlah total penduduk dewasa. Dengan adanya wirausaha masyarakat dapat mempunyai kemampuan untuk menciptakan dan menyediakan produk yang bernilai tambah atau inovasi-inovasi yang baru sehingga dapat menjadikan masyarakat lebih kreatif dalam menyampaikan ide-ide dan kreasinya. Mereka bisa menciptakan barang yang dirasa perlu dan penting untuk kesejahteraan masyarakat itu sendiri 
sehingga tidak perlu mengimpor dari luar negeri.( Widari, Putu "Peran Wirausaha Untuk Meningkatkan Kesejahteraan Masyarakat Indonesia", http://putuarisafitri.blogspot.co.id/2014/01/peran-wirausaha-untuk-meningkatkan.html, diakses pada 23 Juli 2017.)

(Joseph Schumpeter) menekankan pentingnya peranan wirausahawan dalam kegiatan ekonomi suatu negara, sehingga dapat meningkatkan pertumbuhan ekonomi, karena para pengusaha merupakan golongan yang akan terus menerus membuat pembaruan atau inovasi dalam kegiatan ekonomi.

a. Penggunaan teknik produksi yang baru.

b. Penemuan bahan dasar yang baru.

c. Pembukaan daerah pemasaran yang baru.

d. Penggunaan manajemen yang baru.

e. Penggunaan teknik pemasaran yang baru. (Surya Sandi, "Pembangunan Ekonomi", http://www.academia.edu/7449042/182004126-Pembangunan-Ekonomi-pdf. Diakses pada 7 November 2017)

Menurut Undang-undang No 11 Tahun 2009, tentang Kesejahteraan Sosial. Kesejahteraan sosial adalah kondisi terpenuhinya kebutuhan material, spiritual, dan sosial warga negara agar dapat hidup layak dan mampu mengembangkan diri, sehingga dapat melaksanakan fungsi sosialnya. Permasalahan kesejahteraan sosial yang berkembang dewasa ini menunjukkan bahwa ada warga negara yang belum terpenuhi hak atas kebutuhan dasarnya secara layak karena belum memperoleh pelayanan sosial dari negara. Akibatnya, masih ada warga negara yang mengalami hambatan pelaksanaan fungsi sosial sehingga tidak dapat menjalani kehidupan secara layak dan bermartabat.

Pengertian kesejahteraan menurut UU tentang kesejahteraan yakni :

Suatu tata kehidupan dan penghidupan sosial materiil maupun spiritual yang diliputi oleh rasa keselamatan, kesusilaan dan ketentraman lahir batin, yang memungkinkan bagi setiap warga Negara untuk mengadakan usaha pemenuhan kebutuhankebutuhan jasmaniah, rohaniah dan sosial yang sebaik-baiknya bagi diri, keluarga serta masyarakat dengan menjunjung tinggi hak-hak asasi serta kewajiban manusia sesuai dengan Pancasila.( Undang-Undang Nomor 6 tahun 1974, Pasal 2 ayat 1.)

Kesejahteraan adalah salah satu aspek yang cukup penting untuk menjaga dan membina terjadinya stabilitas sosial dan ekonomi, dimana kondisi tersebut juga diperlukan untuk meminimalkan terjadinya kecemburuan sosial dalam masyarakat. Maka setiap individu membutuhkan kondisi yang sejahtera, baik sejahtera dalam hal materil dan dalam hal non materil sehingga dapat terciptanya suasana yang harmonis dalam bermasyarakat.

Kesejahteraan sosial adalah sistem yang terorganisir dari pelayanan-pelayanan sosial dan lembaga-lembaga yang bertujuan untuk membantu individu dan kelompok untuk mencapai standar hidup dan kesehatan yang memuaskan dan relasi-relasi pribadi dan sosial yang memungkinkan mereka mengembangkan kemampuannya sepenuh mungkin dan meningkatkan kesejahteraannya secara selaras dengan kebutuhan keluarga dan masyarakat." Definisi di atas mengandung pengertian bahwa kesejahteraan sosial mencakup berbagai usaha yang dikembangkan untuk meningkatkan taraf hidup manusia manusia, baik itu di bidang fisik, mental, emosional, sosial, ekonomi dan spiritual. (w.google.com/search=teori+kesejahteraan+\&oq=teori+kesejahteraan+\&gs_l=psy- Diunduh tgl 21 Juli 2016 pukul 10.00WIB)

Ukuran Kesejahteraan, Terdapat delapan indikator yang digunakan untuk mengetahui tingkat kesejahteraan masyarakat menurut Badan Pusat Statistik (BPS), diantaranya :

1. Pendapatan : Menurut Badan Pusat Statistik pendapatan rumah tangga adalah pendapatan yang diterima oleh rumah tangga bersangkutan baik yang berasal dari pendapatan kepala rumah tangga maupun pendapatan anggota-anggota rumah tangga. Sajogyo menyatakan bahwa tingkat pendapatan yang tinggi akan memberi peluang yang lebih besar bagi rumah tangga untuk memilih pangan yang lebih baik dalam jumlah maupun mutu gizinya. Pada sisi lain, rendahnya pendapatan akan menyebabkan orang tidak mampu membeli kebutuhan pangan serta memilih pangan yang bermutu gizi kurang serta tidak beragam.( Ringkasan Hasil Survey Evaluasi Proyek UPGK, Edisi ke 2, Lembaga Penelitian Sosiologi Pedesaan, IPB, Bogor)

2. Pengeluaran : Menurut Badan Pusat Statistik pola konsumsi rumah tangga didefinisikan sebagai proporsi pengeluaran rumahtangga yang dialokasikan untuk kebutuhan pangan dan non pangan.

3. Keadaan Tempat Tinggal : Adapun Kriteria tempat tinggal menurut Badan Pusat Sttistik ada 5 item yaitu jenis atap rumah, dinding, status kepemilikan rumah, lantai dan luas lantai.

4. Fasilitas Tempat Tinggal : Berbagai fasilitas yang mencerminkan kesejahteraan rumah tangga dapat dilihat dari kualitas bahan bangunan yang digunakan termasuk juga fasilitas lain yang meliputi sumber air minum, fasilitas MCK dan sumber penerangan. Sesuai dengan kriteria Badan Pusat Statistik fasilitas tempat tinggal dalam penelitian ini diukur dari luas pekarangan, alat elektronik, alat pendingin, sumber penerangan, kendaraan yang dimiliki, bahan bakar untuk memasak, sumber air bersih, fasilitas air minum, cara memperoleh air minum, sumber air minum, MCK dan jarak MCK dari tempat tinggal.

5. Kesehatan Anggota Keluarga: Kesehatan dan gizi merupakan bagian dari indikator kesejahteraan penduduk dalam hal kualitas fisik. Sesuai dengan kriteria Badan Pusat Statistik kesehatan dalam penelitian ini di ukur dari bagaimana kondisi kesehatan dari anggota keluarga apakah dalam kondisi bagus ( $<25 \%$ sering sakit), cukup (25\% - 50\% sering sakit), atau kurang (>50\% sering sakit).

6. Kemudahan Mendapatkan Pelayanan Kesehatan : Pelayanan di bidang kesehatan masyarakat merupakan hak dan kebutuhan yang mendasar yang harus dipenuhi oleh pemerintah. Upaya pemerintah untuk meningkatkan derajat dan status kesehatan penduduk dilakukan antara lain dengan meningkatkan ketersediaan dan keterjangkauan fasilitas dan sarana kesehatan. 
Upaya ini akan memudahkan pengobatan penyakit bagi penduduk yang mengalami keluhan kesehatan. Sesuai dengan kriteria Badan Pusat Statistik kemudahan mendapatkan pelayanan kesehatan dalam penelitian ini di ukur dari jarak rumah sakit terdekat, jarak toko obat, penanganan obat-obatan, harga obat-obatan, dan kemudahan mendapatkan alat kontrasepsi.

7. Kemudahan Memasukkan Anak ke Jenjang Pendidikan : Pendidikan merupakan salah satu cara untuk meningkatkan kualitas Sumber Daya Manusia (SDM), dan SDM yang berkualitas yang merupakan faktor utama keberhasilan pembangunan di suatu negara. Pada dasarnya pendidikan yang diupayakan bukan hanya tanggung jawab pemerintah tapi juga masyarakat dan keluarga. Pemerataan kesempatan pendidikan di upayakan melalui penyediaan sarana dan prasarana belajar. Sesuai dengan kriteria Badan Pusat Statistik kemudahan memasukkan anak ke jenjang pendidikan dalam penelitian ini diukur dari 3 item yaitu biaya sekolah, jarak ke sekolah, dan proses penerimaan dalam bersekolah.

8. Kemudahan Mendapat Fasilitas Transportasi : Dalam hal transportasi penelitian ini diukur dari 3 item yaitu ongkos kendaraan, fasilitas kendaraan, dan status kepemilikan kendaraan. (Badan Pusat Statistik, Indikator Kesejahteraan Rumah Tangga, BPS, Jakarta, 2013)

\section{III.METODE PENELITIAN}

Penelitian ini berlokasi Desa Baderan Kabupaten Ngawi dengan jenis penelitian deskriptif, dan subyek penelitian masyarakat. Tehnik pengumpulan data yang digunakan dalam penelitian ini adalah interview (wawancara), observasi (pengamatan), dan document (dokumentasi). Metode analisis data menggunakan intepretasi data dengan penetapan skala pengukuran skala Likert.

\section{IV.HASIL PENELITIAN}

\section{A. Gambaran Umum Obyek Penelitian}

Asal nama 'baderan' bermula dari keadaan wilayahnya yang terdapat sebuah aliran sungai dimana banyak hidup habitat ikan 'bader', sehingga tempat tersebut menjadi tujuan penduduk sekitar untuk mengambil ikan bader tersebut. Lambat laun daerah tersebut oleh masyarakat tadi disebut 'baderan', yang berarti daerah yang banyak ikan badernya. Adapun riwayat kepemimpinan semenjak berdirinya desa Baderan sampai dengan sekarang;

1. M. Kasim tahun 1965 s.d 1997

2. Nurdjali tahun 1997 s.d 2004

3. Sukamto tahun 2004 s.d 2009

4. Sukamto tahun 2009 s.d 2014

5. Suyanto tahun 2014 s.d 2020

Desa Baderan merupakan salah satu desa dari 13 (tiga belas) desa yang ada di Kecamatan Geneng, Kabupaten Ngawi. Desa Baderan terletak $\pm 5 \mathrm{~km}$ di sebelah tenggara dari ibu kota Kecamatan Geneng. Adapun batas-batas wilayah Desa Baderan Kecamatan Geneng Kabupaten Ngawi adalah sebagai berikut :

a. Sebelah Utara : Desa Sidorejo dan Desa Klampisan (Kecamatan Geneng)

b. Sebelah Timur : Desa Pojok dan Desa Jeruk (Kecamatan Kartoharjo, Kabupaten Magetan)

c. Sebelah Selatan : Desa Bayem (Kecamatan Kartoharjo, Kabupaten Magetan)

d. Sebelah Barat : Desa Keniten (Kecamatan Geneng)

Luas wilayah desa Baderan adalah 421,915 Ha, terdiri dari lahan pertanian, pemukiman, perkebunan, fasilitas umum, dan lain-lain.

Sumber Daya Alam (1) Pertanian : Produksi pertanian paling menonjol di desa Baderan adalah padi. Meskipun produksi padi bila dibandingkan desa lain belum menduduki peringkat atas, namun rata-rata hasil panen mengalami tren yang stabil. Tanaman palawija seperti Kedelai, Ketela Pohon, dan Kacang Tanah juga terus dioptimalkan untuk dikembangkan. (2) Peternakan : Usaha peternakan di desa Baderan antara lain; ternak kambing, ternak sapi, ternak ayam, ternak kerbau, ternak itik, dan ternak kambing boor.

1. Orbitasi

a.Jarak ke Ibu Kota Kecamatan

b.Jarak ke Ibu Kota Kabupaten

c.Jarak ke Ibu Kota Provinsi

d.Jarak ke Ibu Kota Negara
$6 \mathrm{Km}$

$13 \mathrm{Km}$

$181 \mathrm{Km}$

$635 \mathrm{Km}$

2. Demografi

Data demografi bermanfaat untuk mengetahui laju pertumbuhan penduduk dan mengetahui jumlah angkatan kerja yang ada. Data penduduk berdasarkan data administrasi Pemerintah Desa Baderan adalah 4.062 jiwa, yang terdiri dari 1.866 laki-laki dan 2.196 perempuan, dengan Kepala Keluarga (KK) sebanyak 1.420 KK. 
Website : http://sosial.unmermadiun.ac.id/index.php/sosial

Tabel 1

Variabel Tentang Peran Wirausaha

Desa Baderan Kecamatan Geneng Kabupaten Ngawi

\begin{tabular}{|l|c|c|}
\hline Kategori & Jumlah Responden & Prosentase (\%) \\
\hline Baik & 56 & 63,6 \\
\hline Cukup & 22 & 25,0 \\
\hline Tidak Baik & 10 & 11,4 \\
\hline Jumlah & 88 & 100,0 \\
\hline
\end{tabular}

Sumber data : data diolah

Dari tabel tersebut diatas dapat diketahui bahwa dari 88 responden terdapat 56 responden atau 63,6\% termasuk dalam kategori baik, 22 responden atau 25\% dalam kategori cukup dan terdapat 10 orang atau 11,4\% dalam kategori tidak baik.Berdasarkan data di atas, maka dapat disimpulkan bahwa Peran Wirausaha Desa Baderan Kecamatan Geneng Kabupaten Ngawi.

Tabel 2

Klasifikasi Data Variabel Kesejahteraan Ekonomi Masyarakat Desa Baderan Kecamatan Geneng Kabupaten Ngawi

\begin{tabular}{|l|c|c|}
\hline Kategori & Jumlah Responden & Prosentase (\%) \\
\hline Baik & 68 & 77,2 \\
\hline Cukup & 13 & 14,8 \\
\hline Tidak Baik & 7 & 8,0 \\
\hline Jumlah & 88 & 100,0 \\
\hline
\end{tabular}

Sumber data : data diolah

Dari tabel tersebut diatas dapat diketahui bahwa dari 88 responden terdapat 68 responden atau 77,2\% termasuk dalam kategori baik, 13 responden atau $14,8 \%$ dalam kategori cukup dan terdapat 7 orang atau $8 \%$ dalam kategori tidak baik.Berdasarkan data di atas, maka dapat disimpulkan bahwa Kesejahteraan Ekonomi Masyarakat Desa Baderan Kecamatan Geneng Kabupaten Ngawi.

Tabel 3

Perbandingan Variabel Peran Wirausaha Terhadap Kesejahteraan Ekonomi Masyarakat di Desa Baderan Kecamatan Geneng Kabupaten Ngawi

\begin{tabular}{|c|c|c|}
\hline \multirow[t]{2}{*}{ Kategori Jawaban } & \multicolumn{2}{|c|}{ Variabel Penelitian (\%) } \\
\hline & Variabel Bebas & Variabel Terikat \\
\hline Baik & 63,6 & 77,2 \\
\hline Cukup & 25,0 & 14,8 \\
\hline Tidak baik & 11,4 & 8,0 \\
\hline Jumlah : & 100,0 & 100,0 \\
\hline
\end{tabular}

Sumber : Data primer diolah dari tabel 1 dan 2

Berdasarkan tabel di atas dapat diketahui bahwa Peran Wirausaha Desa Baderan Kecamatan Geneng Kabupaten Ngawi menunjukkan nilai sebesar 70,1\% pada kategori baik, sedangkan Kesejahteraan di Desa Baderan Kecamatan Geneng Kabupaten Ngawi menunjukkan $81,8 \%$ pada kategori baik. Dengan demikian dapat disimpulkan peran wirausaha dapat menunjang kesejahteraan di Desa Baderan Kecamatan Geneng Kabupaten Ngawi.

\section{KESIMPULAN}

Peran wirausaha dapat menunjang kesejahteraan di Desa Baderan Kecamatan Geneng Kabupaten Ngawi menunjukkan nilai sebesar 70,1\% pada kategori baik, sedangkan Kesejahteraan di Desa Baderan Kecamatan Geneng Kabupaten Ngawi menunjukkan $81,8 \%$ pada kategori baik. Dengan demikian dapat disimpulkan peran wirausaha dapat menunjang kesejahteraan di Desa Baderan Kecamatan Geneng Kabupaten Ngawi.

Berdasarkan kesimpulan hasil penelitian di atas dapat disampaikan saran sebagai berikut: Hendaknya pemerintah pusat dan daerah berupaya meningkatkan peluang masyarakat khususnya masyaakat desa untuk berwirausaha agar dampaknya dapat meningkatkan kesejahteraan hidup. Hendaknya pemerintah menjembatani dan membantu masyarakat yang sudah memiliki wirausaha untuk mendapatkan peluang membuka cabang di daerah lain. Misalnya dengan memberi kemudahan ijin usaha dan dan bebas pajak usaha bagi pemula.

\section{VI.DAFTAR PUSTAKA}

Buku :

Indarti, Nurul dan Kristiansen, Stein. 2003. Determinants of Entrepreneurial Intention: The Case of Norwegian Students dalam International Journal of Business Gadjah Mada.

Ringkasan Hasil Survey Evaluasi Proyek UPGK, Edisi ke 2, Lembaga Penelitian Sosiologi Pedesaan, IPB, Bogor.

Badan Pusat Statistik, Indikator Kesejahteraan Rumah Tangga, BPS, Jakarta, 2013.

Undang-undang No 11 Tahun 2009, tentang Kesejahteraan Sosial.

Internet :

www.kompasiana.com/www.habibamin.blogspot.com/550e5459813311862cbc625d/pengertian-tujuan-dan-teori-kewirausahaan-materi-kuliah. Diunduh tg1 21 Juli 2016 pukul 06.00WIB 
Website : http://sosial.unmermadiun.ac.id/index.php/sosial

Indarti, Nurul dan Kristiansen, Stein. 2003. Determinants of Entrepreneurial Intention: The Case of Norwegian Students dalam International Journal of Business Gadjah Mada

/akhsan99.wordpress.com/2009/10/14/pengertian-dan-teori-kewirausahaan/ Diunduh tgl 21 Juli 2016 pukul 07.00WIB

http://putuarisafitri.blogspot.co.id/2014/01/peran-wirausaha-untuk-meningkatkan.html, diakses pada 23 Juli 2017.

www.google.com/search=teori+kesejahteraan+\&oq=teori+kesejahteraan+\&gs_l=psy- Diunduh tgl 21 Juli 2016 pukul 10.00WIB

http://www.hukumonline.com/pusatdata/downloadfile/lt4c3c86dcce1e3/parent/242521 Juli 2016 pukul 20.00WIB 